\title{
ROLE OF THE THIOCYANATE ION IN THE CORROSION INHIBITION OF ZINC IN PERCHLORIC ACID BY n-DECYLAMINE
}

\author{
H. B. RUDRESH and S. M. MAYANNA
}

Department of Chemistry, Central College, Bangalore University, Bangalore (India)

(Received June 27, 1978; in revised form August 2, 1978)

\section{Summary}

The effect of KSCN on the corrosion of electropolished zinc in $0.1 \mathrm{M}$ $\mathrm{HClO}_{4}$ and $0.1 \mathrm{M} \mathrm{HClO}_{4}$ solution containing different concentrations of $\mathrm{n}$-decylamine ( $\mathrm{nDA}$ ) has been investigated using weight loss and polarization methods. The inhibitor efficiency of $\mathrm{nDA}$ increased markedly in the presence of KSCN. pH and temperature affected the corrosion inhibition of zinc by $\mathrm{nDA}$ in acidic KSCN solution. The weight loss and polarization measurements gave consistent results. nDA in acidic KSCN solution acted mainly as a cathodic inhibitor, but with a smaller degree of anodic control. The increase in the inhibitor efficiency of $\mathrm{nDA}$ in the presence of KSCN is discussed from the viewpoint of the co-adsorption of $\mathrm{nDA}$ in cationic form and thiocyanate ions.

\section{Introduction}

The study of the corrosion inhibition of metals by amines has been the subject of many investigations. Amines function as corrosion inhibitors in aqueous solution by adsorption at the metal/solution interface [1 - 3]. The extent of adsorption of an inhibitor depends on many factors [4 - 6] : (a) the nature of the metal; (b) the surface condition; and (c) the mode of adsorption of the inhibitor. The adsorption theory of corrosion inhibition, postulating that adsorption is general over the entire surface, was first proposed by Hackerman [7 - 9]. The adsorption of n-decylamine (nDA) on solid electrodes has been reported $[10,11]$. The type of interaction of the corrosion inhibitor on the metal surface has been evaluated from adsorption isotherms [12] . n-Decylamine has been used as a corrosion inhibitor for steel [13]. The corrosion inhibition of zinc in acid solution by $\mathrm{nDA}$ and the synergistic effect of nDA and halide ions have been studied extensively in this laboratory [14-16].

The effect of thiocyanate ion and $\mathrm{nDA}$ on the corrosion of zinc in acid solution was found to be different from the effect of halide ions and nDA. The present communication deals with the effect of the thiocyanate ion on the corrosion inhibition of zinc in perchloric acid solution by $n$-decylamine. 


\section{Experimental}

The materials used for the experiment were $\mathrm{HClO}_{4}(\mathrm{Rdl}) \mathrm{nDA}$ (Fluka $\mathrm{AG}$ ) and $\mathrm{KSCN}(\mathrm{AR})$. The solutions were prepared using fresh triple-distilled water. Zinc (99.999\%) was fixed in Tygon tubing and mechanically polished on 0000 emery paper, using ethanol as lubricant. The electropolishing of the zinc surface was carried out in 35\% (volume) orthophosphoric acid in ethanol at a cell potential of $3.5 \mathrm{~V}$ for $8 \mathrm{~min}$, using a stainless steel plate as cathode $[14,17]$. Free dissolution (spontaneous dissolution) was carried out in a stirred solution of perchloric acid with and without various concentrations of $\mathrm{nDA}, \mathrm{KSCN}$, and mixtures of $\mathrm{KSCN}$ and $\mathrm{nDA}$ at $30^{\circ} \mathrm{C}$. At critical concentrations of addition agents, free dissolution was carried out at different temperatures $\left(30\right.$ to $50{ }^{\circ} \mathrm{C}$ ) and at different concentrations of $\mathrm{HClO}_{4}$ solution.

The weight loss during free dissolution was determined by estimating the amount of zinc dissolved in solution using a colorimetric method [18] .

The anodic and cathodic polarization of zinc was carried out galvanostatically with and without critical concentrations of addition agents. The detailed experimental procedure has been given elsewhere [15] .

\section{Results}

The dissolution of zinc was carried out for various periods of immersion with and without addition agents. Linear variation of weight loss of zinc in

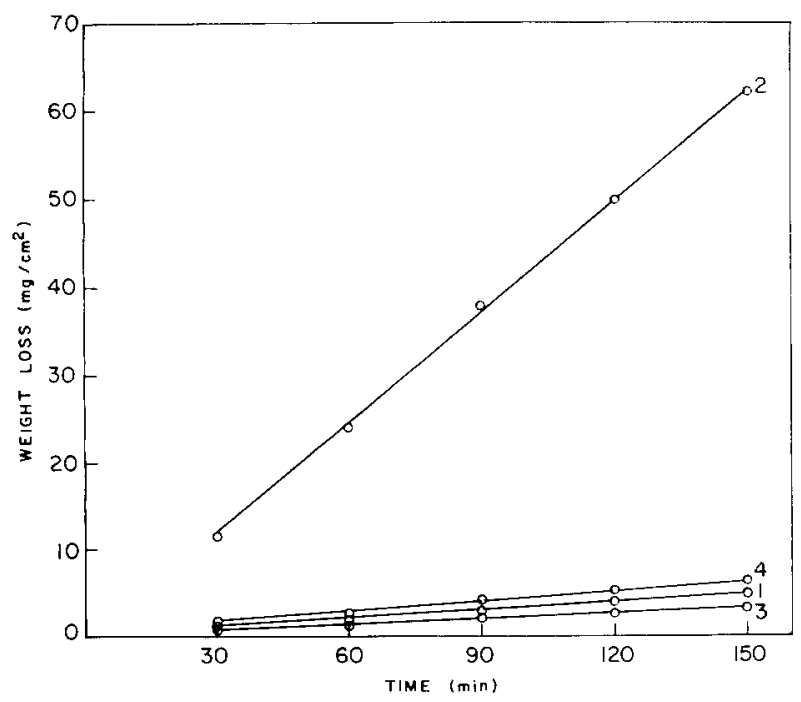

Fig. 1. Variation of weight loss with time at $30{ }^{\circ} \mathrm{C}$ during the corrosion of zine in $0.1 \mathrm{M}$ $\mathrm{HClO}_{4}$ with: (1) no addition agents; (2) $0.01 \mathrm{M} \mathrm{KSCN}$; (3) $5 \times 10^{-3} \mathrm{M} \mathrm{nDA}$; (4) $0.01 \mathrm{M}$ $\mathrm{KSCN}+5 \times 10^{-3} \mathrm{M} \mathrm{nDA}$. 
$\mathrm{HClO}_{4}$ solution with time (Fig. 1) was observed with and without addition agents, indicating steady rate of dissolution.

The weight loss of zinc in $0.1 \mathrm{M}$ perchloric acid solution containing different concentrations of nDA was determined. Table 1 shows the corrosion rate at different concentrations of $\mathrm{nDA}$. The $\mathrm{pH}$ of $0.1 \mathrm{M}$ perchloric acid was not altered by the addition of $\mathrm{nDA}$ up to $10^{-2} \mathrm{M}$. The dissolution rate of zinc decreased with increase in $\mathrm{nDA}$ concentration. $10^{-2} \mathrm{M} \mathrm{nDA}$ decreased the corrosion of zinc from 2.16 to $1.27 \mathrm{mg} \mathrm{cm}^{-2} \mathrm{~h}^{-1}$, indicating $41 \%$ corrosion inhibition. The corrosion potential shifted from $-685 \mathrm{mV}$ to $-650 \mathrm{mV}$ in the presence of $10^{-2} \mathrm{M} \mathrm{nDA}$.

\section{TABLE 1}

Corrosion potential, weight loss and surface coverage at different concentrations of $\mathrm{nDA}$ in $0.1 \mathrm{M} \mathrm{HClO}_{4}$

\begin{tabular}{llll}
\hline Molar concentration & $\begin{array}{l}\text { Corrosion potential } \\
(\mathrm{mV})\end{array}$ & $\begin{array}{l}\text { Weight loss } \\
\left(\mathrm{mg} \mathrm{cm}^{-2} \mathrm{~h}^{-1}\right)\end{array}$ & Surface coverage $\theta$ \\
\hline 0 & -685 & 2.16 & \\
$10^{-3}$ & -680 & 1.92 & 0.11 \\
$2.5 \times 10^{-3}$ & -680 & 1.71 & 0.21 \\
$5 \times 10^{-3}$ & -670 & 1.50 & 0.30 \\
$7.5 \times 10^{-3}$ & -660 & 1.35 & 0.38 \\
$10^{-2}$ & -650 & 1.27 & 0.41 \\
\hline
\end{tabular}

Table 2 shows the effect of KSCN on the corrosion of zinc in $0.1 \mathrm{M}$ $\mathrm{HClO}_{4}$ solution. A marked increase in the corrosion rate was observed with the addition of KSCN. The corrosion rate increased from 2.16 to $24.2 \mathrm{mg}$ $\mathrm{cm}^{-2} \mathrm{~h}^{-1}$ with the addition of $10^{-2} \mathrm{M} \mathrm{KSCN}$ to $0.1 \mathrm{M} \mathrm{HClO}_{4}$ solution. The corrosion potential shifted from $-685 \mathrm{mV}$ to $-760 \mathrm{mV}$ with the addition of $10^{-2} \mathrm{M} \mathrm{KSCN}$. Increasing the concentration of KSCN to $10^{-1} \mathrm{M}$, the corrosion rate and corrosion potential changed to $30.3 \mathrm{mg} \mathrm{cm}^{-2} \mathrm{~h}^{-1}$ and $-780 \mathrm{mV}$, respectively. The smell of $\mathrm{H}_{2} \mathrm{~S}$ and the corrosion product $\mathrm{ZnS}$ on the surface were also noticed during the dissolution in perchloric acid containing KSCN.

The experiments were carried out with different concentrations of nDA in $\mathrm{HClO}_{4}$ solution containing $10^{-2} \mathrm{M} \mathrm{KSCN}$. A significant decrease in the corrosion rate was observed with the addition of nDA. In the presence of $10^{-2} \mathrm{M} \mathrm{nDA}$, the corrosion rate decreased from $24.2 \mathrm{mg} \mathrm{cm} \mathrm{cm}^{-2} \mathrm{~h}^{-1}$ to $2.1 \mathrm{mg} \mathrm{cm} \mathrm{cm}^{-2} \mathrm{~h}^{-1}$, corresponding to $91.3 \%$ inhibition. The corrosion potential also shifted significantly with the addition of nDA to the solution of $\mathrm{HClO}_{4}$ containing $\mathrm{KSCN}$.

Table 3 shows the corrosion rate and corrosion potential at various concentrations of nDA in $\mathrm{HClO}_{4}$ solution containing KSCN.

The effect of KSCN on the corrosion of zinc in perchloric acid containing $\mathrm{nDA}$ was studied. The corrosion inhibition of zinc by $5 \times 10^{-3} \mathrm{M} \mathrm{nDA}$ 
TABLE 2

Effect pf KSCN concentration on corrosion rate and corrosion potential of zinc in $0.1 \mathrm{M}$ $\mathrm{HClO}_{4}$ at $30^{\circ} \mathrm{C}$

\begin{tabular}{lcc}
\hline Molar concentration & $\begin{array}{l}\text { Corrosion rate } \\
\left(\mathrm{mg} \mathrm{cm}^{-2} \mathrm{~h}^{-1}\right)\end{array}$ & $\begin{array}{l}\text { Corrosion potential } \\
(\mathrm{mV})\end{array}$ \\
\hline 0 & 2.16 & -685 \\
$10^{-5}$ & 2.18 & -685 \\
$10^{-4}$ & 3.12 & -690 \\
$5 \times 10^{-4}$ & 7.92 & -700 \\
$10^{-3}$ & 12.40 & -715 \\
$5 \times 10^{-3}$ & 19.40 & -740 \\
$10^{2}$ & 24.20 & -760 \\
$2.5 \times 10^{-2}$ & 26.20 & -765 \\
$5 \times 10^{-2}$ & 27.50 & -770 \\
$7.5 \times 10^{-2}$ & 29.50 & -775 \\
$10^{-1}$ & 30.30 & -780 \\
\hline
\end{tabular}

TABLE 3

Effect of $\mathrm{nDA}$ concentration on dissolution rate, corrosion potential and surface coverage of zinc in $0.1 \mathrm{M} \mathrm{HClO}_{4}+10^{-2} \mathrm{M} \mathrm{KSCN}$

\begin{tabular}{lcll}
\hline Molar concentration & $\begin{array}{l}\text { Corrosion rate } \\
\left(\mathrm{mg} \mathrm{cm}^{2} \mathrm{~h}^{-1}\right)\end{array}$ & $\begin{array}{l}\text { Corrosion potential } \\
(\mathrm{mV})\end{array}$ & Surface coverage 0 \\
\hline 0 & 24.2 & -760 & \\
104 & 20.0 & -750 & 0.17 \\
$2 \times 10^{-4}$ & 18.2 & -740 & 0.26 \\
$5 \times 10^{-4}$ & 15.0 & -720 & 0.38 \\
$10^{-3}$ & 9.30 & -705 & 0.62 \\
$2.5 \times 10^{-3}$ & 6.25 & -695 & 0.74 \\
$5 \times 10^{-3}$ & 2.60 & -690 & 0.89 \\
$7.5 \times 10^{-3}$ & 2.40 & -685 & 0.90 \\
$10^{-2}$ & 2.10 & -685 & 0.903 \\
\hline
\end{tabular}

was found to be only $30 \%$. The inhibition increased with increase in concentration of KSCN. An inhibition of $89 \%$ was noticed in the presence of $5 \times$ $10^{-3} \mathrm{M} \mathrm{nDA}$, when the concentration of KSCN was $5 \times 10^{-3} \mathrm{M}$.

The corrosion potential in $0.1 \mathrm{M} \mathrm{HClO}_{4}$ changed by $15 \mathrm{mV}$ in the presence of $5 \times 10^{-3} \mathrm{MnDA}$. The change in corrosion potential with the same concentration of $\mathrm{nDA}$, in $\mathrm{HClO}_{4}$ containing $\mathrm{KSCN}$, is given in Table 4 .

Free dissolution was carried out at different temperatures in the following baths: (a) $0.1 \mathrm{M} \mathrm{HClO}_{4}$, (b) $0.1 \mathrm{M} \mathrm{HClO}_{4}+0.01 \mathrm{M} \mathrm{KSCN}$, (c) $0.1 \mathrm{M}$ $\mathrm{HClO}_{4}+5 \times 10^{-3} \mathrm{M} \mathrm{nDA}$ and (d) $0.1 \mathrm{M} \mathrm{HClO}_{4}+0.01 \mathrm{M} \mathrm{KSCN}+5 \times 10^{-3}$ $\mathrm{M} n \mathrm{nA}$. Increase in temperature increased the corrosion rate in baths (a) and (b), whereas in solutions (c) and (d), the corrosion rate decreased. Thus, the inhibitor efficiency of $5 \times 10^{-3} \mathrm{M} \mathrm{nDA}$ increased with increase in temper- 


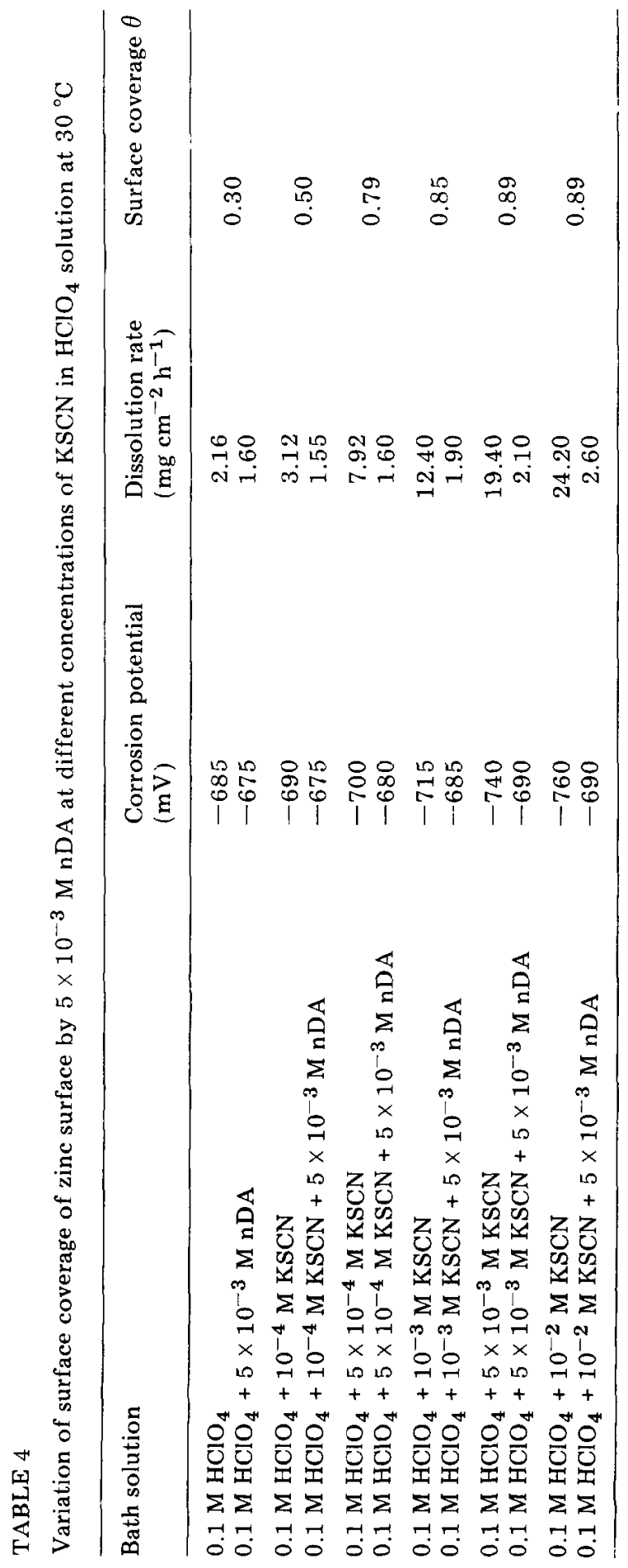


ature, i.e. 0.30 at $30{ }^{\circ} \mathrm{C}$ to 0.50 at $50{ }^{\circ} \mathrm{C}$ in $0.1 \mathrm{M} \mathrm{HClO}_{4}$. In $0.1 \mathrm{M} \mathrm{HClO}_{4}$ containing $5 \times 10^{-3} \mathrm{M} \mathrm{KSCN}$ the inhibitor efficiency of $5 \times 10^{-3} \mathrm{M} \mathrm{nDA}$ increased from 0.89 at $30{ }^{\circ} \mathrm{C}$ to 0.93 at $50{ }^{\circ} \mathrm{C}$. Table 5 shows the inhibitor efficiency of $5 \times 10^{-3} \mathrm{M} \mathrm{nDA}$ at different temperatures.

\section{TABLE 5}

Effect of temperature on corrosion inhibition of zinc by $5 \times 10^{-3} \mathrm{M} \mathrm{nDA}$ in $\mathrm{HClO}_{4}$ with and without KSCN

\begin{tabular}{lll}
\hline $\begin{array}{l}\text { Temperature } \\
\left({ }^{\circ} \mathrm{C}\right)\end{array}$ & \multicolumn{2}{c}{ Percentage protection } \\
\cline { 2 - 3 } & In $0.1 \mathrm{M} \mathrm{HClO}_{4}$ & In $0.1 \mathrm{M} \mathrm{HClO}_{4}+0.01 \mathrm{M} \mathrm{KSCN}$ \\
\hline 30 & 30.5 & 89.0 \\
40 & 42.0 & 91.0 \\
50 & 50.0 & 93.0 \\
\hline
\end{tabular}

The addition of $5 \times 10^{-3} \mathrm{M} \mathrm{nDA}$ did not alter the $\mathrm{pH}$ of $\mathrm{HClO}_{4}$ under study. The inhibitor efficiency of $\mathrm{nDA}$ was also determined at different $\mathrm{pH}$ values by free dissolution experiments. Table 6 indicates the increase in the corrosion inhibition of zine by $\mathrm{nDA}$ with increase in $\mathrm{pH}$.

TABLE 6

Effect of perchloric acid concentration on corrosion inhibition of zinc by $5 \times 10^{-3} \mathrm{M}$ $\mathrm{nDA}$

\begin{tabular}{llll}
\hline Concentration of $\mathrm{HClO}_{4}(\mathrm{M})$ & $\mathrm{pH}$ & \multicolumn{2}{c}{ Percentage protection } \\
\cline { 2 - 4 } & & $\mathrm{In} \mathrm{HClO}_{4}$ & $\mathrm{In} \mathrm{HClO}_{4}+0.01 \mathrm{M} \mathrm{KSCN}$ \\
\hline 0.05 & 1.30 & 39 & 91.5 \\
0.10 & 1.00 & 30 & 89.0 \\
0.25 & 0.60 & 23 & 84.0 \\
0.50 & 0.30 & 19 & 75.0 \\
\hline
\end{tabular}

To understand the mechanism of corrosion inhibition, anodic and cathodic polarization studies were made galvanostatically in $0.1 \mathrm{M} \mathrm{HClO}_{4}$ with and without addition agents at $30{ }^{\circ} \mathrm{C}$ (Figs. 2 and 3). At a particular current density, the polarization decreased with the addition of KSCN, and the polarization increased with the addition of nDA to $0.1 \mathrm{M} \mathrm{HClO}_{4}$. The increase in polarization with the addition of $\mathrm{nDA}$ was more in $0.1 \mathrm{M} \mathrm{HClO}_{4}$ $+0.01 \mathrm{M} \mathrm{KSCN}$ than in $0.1 \mathrm{M} \mathrm{HClO}_{4}$. The anodic Tafel slope of $30 \pm 5 \mathrm{mVs}$ was not changed by the addition of either addition agent, KSCN or nDA. The cathodic Tafel slope of $120 \pm 10 \mathrm{mV}$ was also unaffected by the addition of KSCN. However, the slope increased to $290 \mathrm{mV}$ with the addition of $5 \times 10^{-3} \mathrm{M} \mathrm{nDA}$ to both $0.1 \mathrm{M} \mathrm{HClO}_{4}$ and $0.1 \mathrm{M} \mathrm{HClO}_{4}$ containing $\mathrm{KSCN}$. 


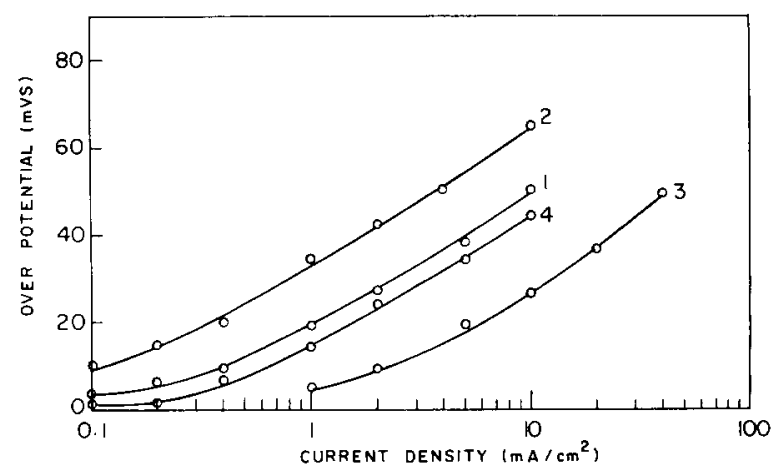

Fig. 2. Galvanostatic anodic polarization of zinc at $30^{\circ} \mathrm{C}$ in $0.1 \mathrm{M} \mathrm{HClO}_{4}$ containing (1) no addition agents; (2) $5 \times 10^{-3} \mathrm{MnDA}$; (3) $0.01 \mathrm{M} \mathrm{KSCN}$; (4) $0.01 \mathrm{M} \mathrm{KSCN}+5 \times 10^{-3}$ $\mathrm{M}$ nDA.

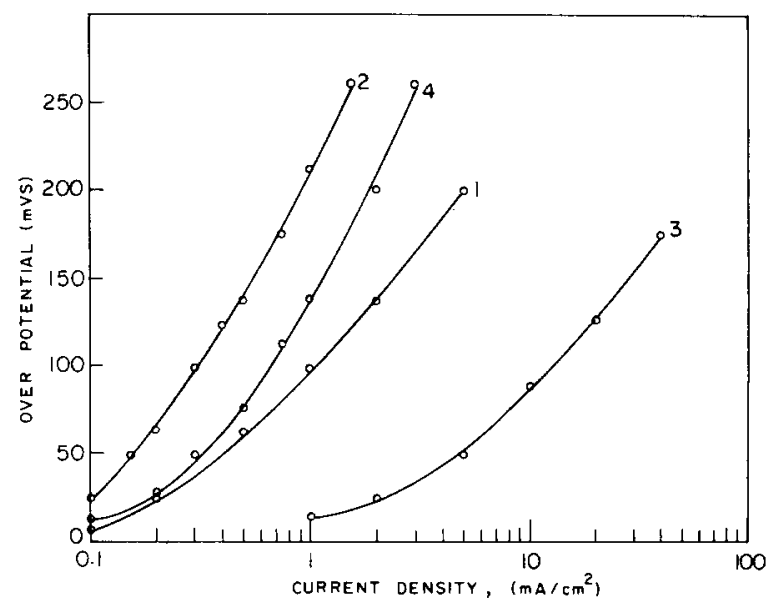

Fig. 3. Galvanostatic cathodic polarization of zinc at $30^{\circ} \mathrm{C}$ in $0.1 \mathrm{M} \mathrm{HClO}_{4}$ containing (1) no addition agents; (2) $5 \times 10^{-3} \mathrm{M} \mathrm{nDA}$; (3) $0.01 \mathrm{M} \mathrm{KSCN}$; (4) $0.01 \mathrm{M} \mathrm{KSCN}+5 \times$ $10^{-3} \mathrm{M} \mathrm{nDA}$.

The corrosion current densities were determined by extrapolating anodic and cathodic Tafel lines to free corrosion potential values. The inhibitor efficiency calculated from the weight loss and the Tafel extrapolation methods are given in Table 7. Consistency in the value of inhibitor efficiency was noted.

\section{Discussion}

The corrosion rate of zinc in $0.1 \mathrm{M} \mathrm{HClO}_{4}$ decreased with the addition of $\mathrm{nDA}$. A marked increase in the corrosion rate was observed with the addition of KSCN to $0.1 \mathrm{M} \mathrm{HClO}_{4}$. The addition of nDA to $0.1 \mathrm{M} \mathrm{HClO}_{4}$ 
TABLE 7

Comparison of surface coverage of $\mathrm{nDA}\left(5 \times 10^{-3} \mathrm{M}\right)$ with and without $\mathrm{KSCN}$ in $\mathrm{HClO}_{4}$ by weight loss and an electrochemical method

\begin{tabular}{llll}
\hline Bath solution & $\begin{array}{l}\text { Corrosion } \\
\text { current } \\
\left(\mathrm{mA} \mathrm{cm}^{-2}\right)\end{array}$ & $\begin{array}{l}\text { Surface coverage } \\
\text { Electrochemical } \\
\text { method }\end{array}$ & $\begin{array}{l}\text { Weight loss } \\
\text { method }\end{array}$ \\
\hline $0.1 \mathrm{M} \mathrm{HClO}_{4}$ & 0.15 & 0.33 & 0.30 \\
$0.1 \mathrm{M} \mathrm{HClO}_{4}+5 \times 10^{-3} \mathrm{M} \mathrm{nDA}$ & 0.10 & & 0.89 \\
$0.1 \mathrm{M} \mathrm{HClO}_{4}+0.01 \mathrm{M} \mathrm{KSCN}$ & 2.0 & 0.90 & \\
$0.1 \mathrm{M} \mathrm{HClO}$ & & \\
$\quad+5 \times 10^{-3} \mathrm{M} \mathrm{nDA}$ & 0.20 & & $\mathrm{MSCN}+$ \\
\hline
\end{tabular}

containing KSCN decreased the corrosion rate of zinc drastically. The inhibitor efficiency of $\mathrm{nDA}$ was a function of the concentration of $\mathrm{nDA}$ and KSCN. Decrease in the corrosion rate was associated with a shift in corrosion potential towards the more noble direction.

The corrosion inhibition of zinc by nDA was affected by the temperature and $\mathrm{pH}$ of the solution. Increase in $\mathrm{pH}$ and temperature increased the inhibitor efficiency of $\mathrm{nDA}$.

The acid corrosion of zinc is electrochemical in nature, consisting of anodic dissolution of zinc with the second electron removal as the ratedetermining step [19] and cathodic hydrogen evolution with the combination of adsorbed hydrogen atom on the surface as the slowest step [20]. The specific adsorption of inhibitor on the surface is the main factor that determines the corrosion inhibition of metals [21]. Halide ions are known to adsorb on the metal surface and the extent of adsorption depends on their polarizability [22] .

The inhibiting action of nDA in $0.1 \mathrm{M} \mathrm{HClO}_{4}$ and the synergistic effect of halide ions during the corrosion inhibition of zinc by $\mathrm{nDA}$ have been extensively discussed from the viewpoint of co-adsorption of halide ions and $\mathrm{nDA}[14,16]$. The free energy of adsorption of $\mathrm{nDA}$ under different conditions is also reported.

The net reaction during the acid corrosion of zinc is

$$
\mathrm{Zn}+2 \mathrm{H}^{+} \rightarrow \mathrm{Zn}^{2+}+\mathrm{H}_{2}
$$

$\mathrm{KSCN}$ in $\mathrm{HClO}_{4}$ may give sulphide ions $\left(\mathrm{S}^{2-}\right)$, which results in the following parallel reactions along with reaction (1)

$$
\begin{aligned}
& \mathrm{Zn}+\mathrm{S}^{2-} \rightarrow \mathrm{ZnS}+2 \mathrm{e} \\
& \mathrm{ZnS}+2 \mathrm{H}^{+} \rightarrow \mathrm{H}_{2} \mathrm{~S}+\mathrm{Zn}^{2+}
\end{aligned}
$$

Hence, one would expect acceleration of the corrosion of zinc in $\mathrm{HClO}_{4}$ solution in the presence of KSCN.

Zine in acid solution has a negative potential on the $\phi$ scale [23]. The protonated $\mathrm{nDA}$ molecules in acid solution tend to adsorb on the cathodic 
sites of the zinc surface, which brings about the inhibition of cathodic evolution of hydrogen. This is in accordance with increase in the cathodic Tafel slope in the presence of $\mathrm{nDA}$ (Fig. 3). The constant anodic Tafel slope in $\mathrm{HClO}_{4}$ solution with and without nDA indicates that the mechanism of anodic dissolution of zinc in $\mathrm{HClO}_{4}$ solution was not changed by $\mathrm{nDA}$ (Fig. 2). However, the displacement of anodic overpotential towards the more noble direction may be due to the blocking of anodic sites on the zinc surface by $\mathrm{nDA}$.

Zine in $\mathrm{HClO}_{4}$ solution containing $\mathrm{KSCN}$ attains a more negative corrosion potential than in $\mathrm{HClO}_{4}$. This favours a better electrostatic condition for $\mathrm{nDA}$ cations to adsorb on the electrode surface. Hence, one would expect an increase in the inhibitor efficiency of $\mathrm{nDA}$ in $\mathrm{HClO}_{4}$ solution containing KSCN (Table 1).

The decrease in the corrosion inhibition of zinc by nDA with decrease in $\mathrm{pH}$ may be explained by the fact that the solubility of $\mathrm{nDA}$ increases with decrease in $\mathrm{pH}$. This decreases the surface concentration of $\mathrm{nDA}$ at the electrode/solution interface, and hence one would expect a decrease in corrosion inhibition with decreasing $\mathrm{pH}$ of the solution. The increase in corrosion inhibition with increase in temperature indicates a strong electrostatic interaction of chemisorbed $\mathrm{nDA}$ cations on the zinc surface.

\section{Acknowledgments}

The authors are grateful to Professor M. Shadaksarawamy, and Professor G. K. Narayana Reddy, Head of the Department of Chemistry, Central College, Bangalore, for their encouragement. One of the authors (H.B.R.) thanks CSIR, New Delhi, for financial support.

\section{References}

1 H. Kaesche and N. Hackerman, J. Electrochem. Soc., 105 (1958) 191.

2 H. F. Finley and N. Hackerman, J. Electrochem. Soc., 107 (1960) 259.

3 R. C. Ayers Jr. and N. Hackerman, J. Electrochem. Soc., 110 (1963) 507.

4 D. A. Vermilyea, 1st Int. Congr. Metal Corrosion, Butterworths, London, 1962, p. 62 .

5 H. Fischer, Werkst Korros., 23 (1972) 445, 453.

6 H. B. Rudresh and S. M. Mayanna, Surf. Technol., 6 (1977) 139.

7 N. Hackerman, Official Digest, 36 (1964) 1405.

8 N. Hackerman, Ann. Univ. Ferrara, Sez. V. Suppl. No. 3, (1961) 99.

9 N. Hackerman and A. C. Mackrides, Ind. Eng. Chem., 46 (1954) 523.

10 J. O'M. Bockris, M. Green and D. A. J. Swinkles, J. Electrochem. Soc., 111 (1964) 743.

11 J. O.'M. Bockris and D. A. J. Swinkles, J. Electrochem. Soc., 111 (1964) 736.

12 S. M. Mayanna, J. Electrochem. Soc., 122 (1975) 251.

13 V. Carassiti, G. Trabenelli and F. Zucchi, 2nd European Symp. Corros. Inhibitors, Univ. Ferrara, 1965, 1966, p. 417.

14 H. B. Rudresh and S. M. Mayanna, J. Electrochem. Soc., 124 (1977) 340. 
15 H. B. Rudresh and S. M. Mayanna, Brit. Corros. J., 12 (1977) 54.

16 H. B. Rudresh and S. M. Mayanna, Corros. Sci., in the press.

17 P. A. Jacquet, Met. Rev., 1 (1956) 157.

18 E. B. Sandell, Colorimetric Determination of Traces of Metals, Wiley-Interscience, New York, 1944, p. 449.

19 T. Hurlen, Acta Chem. Scand., 16 (1962) 1337, 1346.

20 N. Pentland, J. O'M. Bockris and F. J. Sheldon, J. Electrochem. Soc., 104 (1957) 182.

21 Z. A. Iofa and A. A. Medvedeva, Dokl. Akad. Nauk SSSR, 69 (1940) 213.

22 J. M. Kolotyrkin, J. Electrochem. Soc., 108 (1961) 209.

23 L. I. Antropov, Kinetics of Electrode Process and Null Points of Metals, Catholic Press, India, 1960, p. 7. 